\title{
A novel TGF- $\beta$ receptor II mutation (I227T/ N236D) promotes aggressive phenotype of oral squamous cell carcinoma via enhanced EGFR signaling
}

Hwa-Kyung Son ${ }^{1 \dagger}$, Dokyeong Kim²,3+ , Yongwoon $\mathrm{Lim}^{4}$, Jin $\mathrm{Kim}^{3}$ and Iha Park ${ }^{5^{*}}$ (D)

\begin{abstract}
Background: Transforming growth factor- $\beta$ (TGF- $\beta$ ) signaling is a double-edged sword in cancer development and progression. TGF- $\beta$ signaling plays a tumor suppressive role during the early stages of tumor development but promotes tumor progression in later stages. We have previously identified various mutations of TGF- $\beta$ receptor II (TRRII) in human oral squamous cell carcinoma (OSCC) samples. In the present study we analyzed I227T/N236D mutation of TRRII, which was detected in the metastatic lymph node of an OSCC patient.

Methods: The effect of 1227T/N236D TRRII mutation on transcriptional activities was measured using DR26 cells,

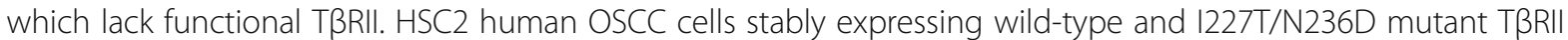
were generated and used to examine the effect of I227T/N236D TßRII mutation on xenograft tumor growth, in vitro cell proliferation, apoptosis, migration, and invasion.

Results: The 1227T/N236D mutation of T $\beta R \|$ upregulated TGF- $\beta$ signaling and promoted xenograft tumor growth when compared with the wild-type, without affecting the in vitro proliferative capacities. To delineate the differences in proliferative capacities in vivo and in vitro, the apoptotic and survival signals were analyzed following curcumin treatment. Concomitant with apoptotic induction, epidermal growth factor receptor (EGFR) activation was observed upon curcumin treatment, which was further activated in 1227T/N236D mutant transfectant cells when compared with wild-type cells. Enhanced EGFR activation correlated with cell survival and apoptotic resistance. Enhanced migratory and invasive capabilities of I227T/N236D mutant cells also depended on EGFR signaling.

Conclusions: These results suggest that enhanced EGFR signaling via upregulated TGF- $\beta$ signaling shifted the balance toward survival and promoted cell migration and invasion in 1227T/N236D mutant cells, elucidating the role of 1227T/N236D mutation of TßRII in OSCC progression.
\end{abstract}

Keywords: Transforming growth factor- $\beta$ type II receptor, Oral squamous cell carcinoma, Epidermal growth factor receptor, Migration, Invasion

\footnotetext{
* Correspondence: ip071@hanmail.net

${ }^{\dagger}$ Hwa-Kyung Son and Dokyeong Kim are first author and contributed equally

to this work.

${ }^{5}$ Department of Biochemistry, Research Center for Aging and Geriatrics,

Research Institute of Medical Sciences, Chonnam National University Medical

School, Hwasun 58128, Republic of Korea

Full list of author information is available at the end of the article
}

(c) The Author(s). 2020 Open Access This article is licensed under a Creative Commons Attribution 4.0 International License, which permits use, sharing, adaptation, distribution and reproduction in any medium or format, as long as you give appropriate credit to the original author(s) and the source, provide a link to the Creative Commons licence, and indicate if changes were made. The images or other third party material in this article are included in the article's Creative Commons licence, unless indicated otherwise in a credit line to the material. If material is not included in the article's Creative Commons licence and your intended use is not permitted by statutory regulation or exceeds the permitted use, you will need to obtain permission directly from the copyright holder. To view a copy of this licence, visit http://creativecommons.org/licenses/by/4.0/ The Creative Commons Public Domain Dedication waiver (http://creativecommons.org/publicdomain/zero/1.0/) applies to the data made available in this article, unless otherwise stated in a credit line to the data. 


\section{Background}

Transforming growth factor- $\beta$ (TGF- $\beta$ ) plays a critical role in biological processes, including development, homeostasis, fibrosis, and carcinogenesis [1-4]. TGF- $\beta$ initiates signaling across the plasma membrane to the nucleus by binding to TGF- $\beta$ type II receptor (T $\beta$ RII) which, in turn, recruits TGF- $\beta$ type I receptor $[5,6]$. Following TGF- $\beta$ receptor activation, receptor-associated Smad proteins (R-Smads), such as Smad2 and Smad3, are phosphorylated. Phosphorylated R-Smads recruit Smad4, and then, translocate to the nucleus to activate transcription of downstream target genes $[4,7,8]$. In addition to this canonical TGF- $\beta$ signaling pathway, TGF- $\beta$ also activates Smad-independent non-canonical pathways, including PI3K/ AKT, mitogen-activated protein kinases (MAPKs), NF-kB, Rho/Rac1, Cdc42, FAK, Src, and Abl $[4,9]$. TGF- $\beta$ signaling is a double-edged sword in cancer development and progression. In the early stages of tumorigenesis, TGF- $\beta$ functions as a tumor suppressor by inducing cell cycle arrest and apoptosis. Paradoxically, TGF- $\beta$ signaling can exacerbate malignant phenotypes at later stages of tumorigenesis, by inducing epithelial-mesenchymal transition (EMT), tumor angiogenesis, and anti-immune reactions [4, 9-11]. Overexpression of TGF- $\beta 1$ correlates with progression of carcinomas, including breast, colon, esophageal, gastric, lung, ovarian, and pancreatic cancers. In contrast, weak or no TGF- $\beta$ signaling due to mutations of T $\beta R I I$, have been found in gliomas, biliary, breast, colon, esophageal, gastric, lung, ovarian, esophageal, pancreatic, prostate, and head and neck cancers [7, 11, 12]. Oral squamous cell carcinoma (OSCC) represents one of the most common types of malignant tumors in head and neck. OSCC develops via stereotypical multistep processes. Abnormal TGF- $\beta$ signaling has been proposed as one of the pathways leading to the carcinogenesis of OSCC [13]. Yet, it is largely unclear how abnormal TGF- $\beta$ signaling contributes to carcinogenesis of OSCC.

We have previously reported various mutations of TßRII detected in 18 human OSCC samples [12]. In the present study, we investigated the I227T/N236D missense mutation located in the intracellular domain of TßRII, which harbors ACC (Thr) instead of ATC (Ile) at codon 227, and GAC (Asp) instead of AAC (Asn) at codon 236 (I227T/N236D). I227T/N236D mutation of T $\beta R I I$, a novel mutation which has not been previously reported, was detected in the metastatic lymph node of one OSCC patient. We analyzed the effect of I227T/ N236D T $\beta$ RII mutation on TGF- $\beta$ signaling and elucidated its role in the functional alterations leading to OSCC development.

\section{Methods}

Antibodies, plasmids, and other reagents

Matrigel (BD Matrigel Matrix, \#356234) and type I collagen (\#637-00653, Cellmatrix type I-A) were purchased from BD Biosciences (San Diego, CA, USA) and Nitta Gelatin (Osaka, Japan), respectively. Recombinant human TGF- $\beta 1$ (\#616455) was purchased from Calbiochem (Merck KGaA, Darmstadt, Germany). Curcumin (\#C1386) and 3-(4,5-methylthiazol-2-yl)-2,5-diphenyltetrazolium bromide (MTT) (\#M5655) were obtained from Sigma-Aldrich (Merck KGaA, Darmstadt, Germany). Antibodies against TRRII (\#sc-220, 1:1000) were purchased from Santa Cruz Biotechnology (CA, USA). Antibodies against phospho-Smad2 (Ser465/467, \#3101, 1: 1000), Smad2 (\#3122, 1:1000), cleaved Caspase-3 (\#9661, 1:1000), cleaved PARP (\#9541, 1:1000), epidermal growth factor receptor (EGFR) (\#2232, 1:1000), phospho-EGFR (Tyr1068, \#2234, 1:1000), phospho-Akt (Ser473, \#9271, 1: 1000), Akt (\#9272, 1:1000) were purchased from Cell Signaling Technology, Inc. (Danvers, MA, USA). Antibodies against $\beta$-actin (\#BS6007M, 1:5000) were obtained from Bioworld Technology, Inc. (St. Louis, MN, USA). Tyrphostin AG 1478 (\#9842), a selective EGFR inhibitor, was purchased from Cell Signaling Technology, Inc. The cDNA for human TßRII (\#RC519855) was purchased from Origene (Rockville, MD, USA). p3TP-lux (\#11767) and pRL-TK (Renilla reniformis luciferase under thymidine kinase promoter) (\#E2241) were obtained from Addgene (Cambridge, MA, USA) and Promega (Madison, WI, USA), respectively. Restriction enzymes were purchased from New England Biolabs (Beverly, MA, USA). Primers for cloning and mutagenesis were synthesized by Bioneer (Daejeon, South Korea). Phusion High-Fidelity DNA Polymerase (\#F530S) for TRRII cloning and mutagenesis was supplied by Thermo Fisher Scientific, Inc. (Carlsbad, CA, USA).

\section{Cells and transient transfection}

DR26 cells, mutant derivatives of Mv1Lu mink lung epithelial cells, which lack functional TßRII, were generously provided by Dr. J. Massague (Memorial SloanKettering Cancer Center, New York, NY, USA). DR26 cells were cultured in Dulbecco's modified Eagle's medium (DMEM, \#12-604F, Biowhittaker, Inc., Walkersville, MD, USA) supplemented with $10 \%$ fetal bovine serum (FBS, \#26140079, Gibco, Thermo Fisher Scientific, Inc., Waltham, MA, USA) and $1 \%$ penicillin/ streptomycin (\#15140-163, Gibco, Thermo Fisher Scientific, Inc.) at $37^{\circ} \mathrm{C}$ in the presence of $5 \% \mathrm{CO}_{2}$. $\mathrm{HSC}-2$ human OSCC cells were kindly provided by Prof. Takashi Muramatsu (Tokyo Dental College, Tokyo, Japan). HSC-2 cells were cultured in P medium (DMEM:Ham's F-12; 3:1) supplemented with $10 \%$ FBS and $1 \%$ penicillin/streptomycin. Ham's F-12 (\#21700-075) was purchased from Thermo Fisher Scientific, Inc. Cells were transiently transfected using Lipofectamine 2000 (\#11668-019, Invitrogen, Thermo Fisher Scientific, Inc.), following the manufacturer's instructions. 


\section{Mutagenesis}

The I227T/N236D double mutant TßRII was obtained by sequential site-directed mutagenesis. First, a T $\beta R I I$ mutant with a threonine residue instead of isoleucine at amino acid 227 (I227T) was constructed by site-directed mutagenesis using PCR as described in our earlier report [10]. cDNA encoding full-length human T $\beta R I I$ was previously subcloned into pcDNA3 and pIRES2-EGFP vectors [10]. These plasmids were used as templates for PCR. Primers 5' -TTGGATCCGGGGTCTGCCATGG GTC-3' (F-BamHI) and 5'-AATCTAGACTATTTGG TAGTGTTTAGGGAGC-3' (R-Xbal) were used to clone TRRII in pcDNA3; $5^{\prime}$-TTCTCGAGGGGGTCTG CCATGGGTC-3' (F-XhoI) and 5'-AAACCGCGGC TATTTGGTAGTGTTTAGGGAGCC-3' (R-SacII) were used to clone TRRII in pIRES2-EGFP. Primers used for site-directed mutagenesis are as follows: 5 '-GCCATCATCC TGGTAGATGACCGCTC-3' (sense) and 5'-GAGCGGTC ATCTACCAGGATGATGGC-3' (antisense). The PCR was performed using primers, F-BamHI (F-XhoI) with antisense and sense with R-XbaI (R-SacII). Subsequently, using the products of first PCR, a second round of PCR was carried out using the primers, F-BamHI (F-Xhol) and R-XbaI (RSacII). The mutant PCR product was ligated to the corresponding restriction enzyme sites of the vector to generate the I227T mutant T $\beta$ RII in pcDNA3 or pIRES2-EGFP. The N236D mutant T $\beta$ RII was constructed in a similar fashion, using primers, 5' -CAACATCAACCACATCACAGAG CTGCTG-3' (sense) and 5'-CAGCAGCTCTGTGATGTG GTTGATGTTG-3' (antisense). I227T mutant TßRII plasmids were used as templates for the second PCR mutagenesis. The integrity of the products was confirmed by sequencing.

\section{Construction of stable transfectant cells expressing T $\beta$ RII} HSC-2 cells stably expressing wild-type or I227T/N236D mutant T $\beta$ RII were constructed, as previously described [10]. After transfection with pIRES2-EGFP vector, wild-

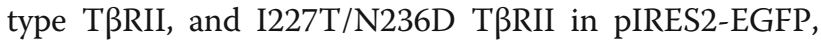
the cells were selected in a P medium containing $10 \%$ FBS and $400 \mathrm{ng} / \mathrm{ml}$ of G418 (\#G8168, Sigma-Aldrich).

\section{Promoter-reporter assay}

3TP-lux promoter-reporter was used to test the transcriptional activities induced by T $\beta$ RII mutation. DR26 cells seeded in 24-well plates were transfected with $0.2 \mu$ $\mathrm{g}$ of 3TP-lux promoter-reporter constructs, $0.2 \mu \mathrm{g}$ of wild type or mutant T $\beta$ RII in pcDNA3, and $0.5 \mu \mathrm{g}$ of pRL-TK. At $24 \mathrm{~h}$ after the transfection, cells were stimulated with $1 \mathrm{ng} / \mathrm{ml}$ of TGF- $\beta$ in DMEM containing $0.2 \%$ FBS. After incubation for $24 \mathrm{~h}$, the firefly luciferase and Renilla luciferase activities were detected using Dual Luciferase Reporter Assay System (\#E1910, Promega, Madison, WI, USA), according to the manufacturer's instructions. Data were normalized to Renilla luciferase activity for evaluation of transfection efficiency.

\section{Cell viability assay}

Cell viability was measured by MTT assay as previously described [10]. For cytotoxicity analysis, cells $\left(1 \times 10^{4}\right)$ were seeded into the individual wells of a 96-well plate and treated with curcumin, AG1478 in the P medium containing $0.2 \%$ FBS. The optical density was measured at $570 \mathrm{~nm}$ using a microplate reader. All experiments were performed in triplicate.

\section{Western blot analysis}

The cells $\left(1 \times 10^{6}\right)$ were washed with cold PBS and lysed with Cell Lysis Buffer (\#9803S, Cell Signaling Technology, Inc.) supplemented with phenylmethylsulfonyl fluoride (PMSF, \# 78830, Cell Signaling Technology, Inc.). Protein concentration was determined using the Bicinchoninic Acid Protein Assay Kit (Pierce, Thermo Fisher Scientific, Inc.). Proteins $(50 \mu \mathrm{g})$ were separated on $10 \%$ SDS-PAGE and transferred to PVDF membranes (\#162-0177, Millipore, Billerica, MA, USA). The membranes were blocked in TBST (Tris-buffered saline with $0.5 \%$ of Triton X100) containing $5 \%$ non-fat milk or BSA for $1 \mathrm{~h}$ at room temperature and incubated with appropriate primary antibodies at $4{ }^{\circ} \mathrm{C}$ overnight. After three washes with TBST, the membranes were incubated with horseradish peroxidase-conjugated anti-mouse (\#7076S) or anti-rabbit (\#7074S) secondary antibodies (Cell Signaling Technology, Inc.) for $1 \mathrm{~h}$. Protein bands were visualized using chemiluminescence reagent (\#W3651-024, GenDEPOT, Barker, TX, USA). The ImageJ software was used to quantify the signal intensity of protein bands.

\section{RNA interference}

Two different small interfering RNA (siRNA) sequences were used to target EGFR. The siRNAs were synthesized by Bioneer and the sequences were as follows: siEGFR\#1 sense, 5'-GCAAAGUGUGUAACGGAAUAGGUAU-3' and antisense, 5' -AUACCUAUUCCGUUACACACUUUGC-3'; siEGFR\#2 sense, 5'-GAGGAAAUAUGUACUACGA-3' and antisense, 5' -UCGUAGUACAUAUUUCCUC-3' (antisense). A negative control siRNA (\#SN-1003) was also purchased from Bioneer. Cells $\left(4 \times 10^{5}\right)$ were cultured in $60 \mathrm{~mm}$ dishes for $24 \mathrm{~h}$. siRNA (100 nM) transfections were carried out using Lipofectamine RNAiMAX (\#13778-075, Invitrogen, Thermo Fisher Scientific, Inc.), according to the manufacturers' instructions. After $6 \mathrm{~h}$ of incubation, medium was replaced to fresh P medium containing 10\% FBS and cells were cultured for an additional $42 \mathrm{~h}$ at $37^{\circ} \mathrm{C}$. For invasion assay, siRNA-transfected cells were 
stabilized for $18 \mathrm{~h}$ after the addition of fresh medium, and then, seeded into the upper chamber of transwell inserts.

\section{Transwell migration assay and scratch wound healing assay}

Two methods, transwell migration assay and scratch wound healing assay, were used to evaluate cell motility. In transwell migration assay, cells $\left(2 \times 10^{4}\right)$ were serum-starved for $16 \mathrm{~h}$ in $\mathrm{P}$ medium and seeded into the upper chamber of transwell inserts $(8 \mu \mathrm{m}$ pore size; \#3422, Corning Costar, Lowell, MA, USA) with or without TGF- $\beta 1(10 \mathrm{ng} / \mathrm{ml})$. The lower chamber contained P medium supplemented with 10\% FBS. After $24 \mathrm{~h}$ of incubation, cells that have migrated to the lower compartment were fixed in $10 \%$ formalin and stained with $0.025 \%$ crystal violet. The membrane filters were mounted on slides, and cells were counted under a microscope (five images per group; magnification, $\times 100)$. In scratch wound healing assay, cells $\left(1 \times 10^{5}\right)$ were seeded into 6 -well plates and transfected with siRNAs. At $48 \mathrm{~h}$ post-transfection, the cell monolayer was wounded with a $200 \mu \mathrm{l}$ sterile pipette tip. Cells were washed once with PBS and fresh serum-free medium was added with or without TGF- $\beta 1(10 \mathrm{ng} / \mathrm{ml})$. Following $18 \mathrm{~h}$ of incubation, migrated cells were counted under a light microscope (magnification, $\times 100)$.

\section{Invasion assay}

Transwell invasion assays were performed in a fashion similar to transwell migration assay except that the membrane inserts were precoated with $50 \mu \mathrm{l} \mathrm{of} 100 \mu \mathrm{g} /$ $\mathrm{ml}$ Matrigel or $30 \mu \mathrm{l}$ of $1.5 \mathrm{mg} / \mathrm{ml}$ Cellmatrix Type I-A. Briefly, after serum starvation for $16 \mathrm{~h}$ in $\mathrm{P}$ medium, cells $\left(2 \times 10^{4}\right)$ were seeded into the transwell chamber inserts in the presence or absence of TGF- $\beta 1(10 \mathrm{ng} / \mathrm{ml})$. The $\mathrm{P}$ medium containing 1\% FBS was added to the lower chamber. After $48 \mathrm{~h}$ of incubation, cells that have penetrated the filter were fixed and stained with $0.025 \%$ crystal violet, and counting under a light microscope (five images per group; magnification, $\times 100$ ).

\section{Gelatin zymography}

Gelatinase activities of matrix metalloproteinase-2 (MMP-2) and matrix metalloproteinase-9 (MMP-9) were analyzed by gelatin zymography as described previously [10]. Cells were seeded in 6-well plates and incubated in $\mathrm{P}$ medium containing $0.2 \% \mathrm{FBS}$ in the presence of vehicle or TGF- $\beta 1(10 \mathrm{ng} / \mathrm{ml})$ for $24 \mathrm{~h}$. Cell conditioned medium $(15 \mu \mathrm{g}$ protein) was subjected to $10 \%$ SDSPAGE containing $0.1 \%$ gelatin under non-reducing conditions. After rinsing four times with $2.5 \%$ triton X-100 to remove SDS at room temperature, the gels were incubated overnight at $37^{\circ} \mathrm{C}$ in a developing buffer $(50 \mathrm{mM}$
Tris- $\mathrm{HCl}, \mathrm{pH} 7.5,0.2 \mathrm{M} \mathrm{NaCl}, 5 \mathrm{mM} \mathrm{CaCl} 2 \cdot 2 \mathrm{H}_{2} \mathrm{O}$, and $0.02 \%$ Brij-35, pH 7.6). The gels were stained with $0.5 \%$ Coomassie Brilliant Blue R-250 in 10\% acetic acid and $50 \%$ methanol, and then destained with 50\% methanol and $10 \%$ acetic acid solution.

\section{Annexin V/propidium iodide (PI) apoptosis assay}

Cells $\left(1 \times 10^{6}\right)$ were seeded in a $100 \mathrm{~mm}$ dish and incubated at $37^{\circ} \mathrm{C}$ overnight. The cells were treated with $20 \mu \mathrm{M}$ curcumin for $24 \mathrm{~h}$, and then, stained with an FITC annexin V apoptosis detection kit (\#556547, BD Pharmingen $^{\mathrm{T}}$, BD Biosciences, San Jose, CA, USA), according to the manufacturers' instructions. Briefly, the cells were harvested and resuspended in binding buffer at a density of $1 \times 10^{6}$ cells $/ \mathrm{ml}$. After the addition of annexin V-FITC $(5 \mu \mathrm{l})$ and PI $(20 \mu \mathrm{g} / \mathrm{ml}, 5 \mu \mathrm{l})$, the cells were incubated for $15 \mathrm{~min}$ at room temperature. Stained cells were analyzed by flow cytometry (BD FACSCanto II flow cytometer, BD Biosciences, Franklin Lakes, NJ, USA). Cytomics FC 500 with CXP software (Beckman Coulter, Fullerton, CA, USA) was used for data analysis.

\section{In vivo xenograft tumor growth assay}

All the animal procedures were performed in accordance with a protocol approved by the Institutional Animal Care and Use Committee of Yonsei University. Fiveweek-old male BALV/c nude mice were purchased from Central Laboratory Animal Inc. (Seoul, Korea). All the mice were housed in the Yonsei Laboratory Animal Research Center and maintained in a pathogen-free environment ( $12 \mathrm{~h}$ light/dark cycle, $25 \pm 2{ }^{\circ} \mathrm{C}$; humidity, $50 \pm 10 \%$ ). Food and water were freely available. HSC-2 stable transfectant cells $\left(2 \times 10^{5}\right.$ cells in $100 \mu \mathrm{l} \mathrm{P}$ medium) were orthotopically injected into the anterior tongue of the mice. Development of tongue tumors and weight loss was regularly monitored for 4 weeks. Tongue tissues containing tumor were fixed in $10 \%$ formalin neutral solution for at least $24 \mathrm{~h}$ at room temperature and embedded in paraffin. The tissues were sectioned into 4- $\mu \mathrm{m}$-thick slices and stained with hematoxylin and eosin (H\&E; \#H-3502, Vector Laboratories, Inc., Burlingame, CA, USA). Tumor volume (TV) was calculated according to the formula: $\mathrm{TV}=\left(\mathrm{AxB}^{2}\right) / 2$, by measuring the diameters of the major axis (A) and the minor axis (B) of tumor [14].

\section{Immunohistochemistry}

4- $\mu \mathrm{m}$ thick sections were cut from the paraffin blocks and immunostained as described [10]. Sections were deparaffinized in xylene, and hydrated in descending grades of ethanol. Sections were incubated with $3 \%$ hydrogen peroxide to inactivate endogenous peroxidase activities. After blocking in 1\% normal goat serum (\#S1000, Vector Laboratories, Inc.) for $1 \mathrm{~h}$, the sections 
were incubated with primary antibodies against phospho-EGFR (1:100) overnight at $4{ }^{\circ} \mathrm{C}$, followed by incubation with biotinylated anti-rabbit IgG (\#BA-1000, Vector Laboratories, Inc.) for $30 \mathrm{~min}$. The sections were then incubated with horseradish peroxidase streptavidin (\#SA-5004, Vector Laboratories, Inc.) for $30 \mathrm{~min}$. The signal was developed using the 3,3' diaminobenzidine tetrahydrochloride (DAB) kit (\#SK-4100, Vector Laboratories, Inc.) and counterstained with Meyer's hematoxylin (\#H3404, Vector Laboratories, Inc.). The staining intensity of the phosphorylated EGFR on the cell membrane was manually scored. An intensity scale ranging from 0 for no staining to $3+$ for the most intense staining is used. H-Score is calculated using the following formula: $\mathrm{H}-$ Score $=(\%$ at 0$) \times 0+$ (\%at $1+) \times 1+(\%$ at $2+) \times 2+(\%$ at $3+) \times 3$.

\section{Statistical analysis}

Mann-Whitney $U$ test was performed for statistical analysis. All variables were analyzed from three independent experiments, and each experiment was performed at least in triplicate. The results are shown as the mean \pm standard deviation. A $P$-value $<0.05$ was considered as statistically significant.

\section{Results \\ Analysis of canonical TGF- $\beta$ signaling by 1227T/N236D TßRII}

We have previously identified various mutations of TRRII in human OSCC samples [12]. In this study, we analyzed the effect of one of these mutations, I227T/ N236D, on tumor proliferation, migration, and invasion. Since I227T/N236D mutation was detected only in the metastatic lymph node, but not in the primary tumor, of an OSCC patient, we speculated this mutation could have been linked to functional alterations of TßRII leading to OSCC progression. First, we analyzed the transcriptional activities of wild-type and I227T/N236D mutant T $\beta$ RII. 3TP-lux reporter contains three consecutive TPA response elements and TGF- $\beta$-responsive portion of human plasminogen activator inhibitor 1 (PAI-1) gene, linked to a luciferase reporter gene $[5,15]$. We used 3TP-lux reporter to measure the transcriptional activities of wild-type and I227T/N236D mutant T $\beta$ RII. DR26 cells without functional T $\beta R I I$, were transiently co-transfected with 3TP-Lux, pRL-TK, and TBRII cDNAs, such as wild-type, I227T, N236D, and I227T/ N236D TRRII. Cells were then treated with either vehicle or $1 \mathrm{ng} / \mathrm{ml}$ of TGF- $\beta 1$ for $24 \mathrm{~h}$. In the absence of TGF- $\beta 1$, both wild-type and mutant T $\beta$ RII expressions exerted basal level transcriptional activities. Upon TGF$\beta 1$ treatment, the transcriptional activity in all cells increased at least 5-fold when compared to mock treatment. When treated with TGF- $\beta 1$, the transcriptional activity of mutant was significantly higher as compared to that of wild-type T $\beta$ RII: 1.6-fold for I227T, 2.9-fold for N236D, and 2.1-fold for I227T/N236D mutant $(p<0.05)$ (Fig. 1a). These data suggest that I227T/N236D mutation of T $\beta$ RII could enhance TGF- $\beta$ signaling.

To determine the effect of I227T/N236D mutation on TGF- $\beta$ signaling in human OSCC cells, HSC- 2 cells were stably transfected with the empty vector, wild-type, and I227T/N236D mutant T $\beta$ RII constructs. The expression

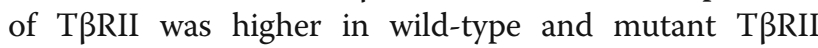
transfectant cells than in mock transfectant cells, indicating the expression of exogenous T $\beta$ RII in these stable cells (Fig. 1b, Additional file 1: Figure S1). Next, we investigated whether exogenous T $\beta$ RII expression activates TGF- $\beta$ downstream signaling by analyzing Smad2 phosphorylation level (Fig. 1c, Additional file 2: Figure S2). Upon treatment with TGF- $\beta$, Smad2 phosphorylation level was significantly increased in mutant cells as compared to wild-type cells $(p<0.01)$. Taken together, these results strongly imply that the I227T/N236D mutation of T $\beta$ RII enhances TGF- $\beta$ signaling in human OSCC cells.

\section{Effects of I227T/N236D T $\beta$ RII mutation in vivo}

To elucidate the effect of upregulated TGF- $\beta$ signaling by $\mathrm{I} 227 \mathrm{~T} / \mathrm{N} 236 \mathrm{D}$ mutation in HSC-2 cells, we measured the proliferative capacities of the stable cells in the presence or absence of TGF- $\beta 1$. There was no significant difference in in vitro growth between wild type and I227T/ N236D mutant cells regardless of the presence of TGF$\beta 1$ (Additional file 3: Figure S3). These findings indicate that HSC-2 cells are resistant to growth inhibition by TGF- $\beta$ signaling, as previously reported [10]. Next, we used a human tumor xenograft mouse model to analyze the effect of I227T/N236D mutation on in vivo proliferative capabilities. Tongue tumors developed in all mice at 4 weeks post-injection into the anterior tongue $(n=5$ to 8 mice per group). Mice injected with I227T/N236D mutant cells developed 7- and 3-fold larger tumors as compared to mice injected with IRES or wild type cells $(p<0.05)$, respectively (Fig. $2 \mathrm{a}$ and $\mathrm{b})$. Taken together, these data indicate that enhanced TGF- $\beta$ signaling by I227T/N236D mutation of T $\beta$ RII promotes tumor growth in vivo.

\section{Migratory and invasive capabilities of I227T/N236D T $\beta$ RII HSC-2 cells}

We next examined the invasive and migratory capabilities of I227T/N236D T $\beta$ RII. First, a transwell migration assay was performed. As a chemoattractant, the complete medium containing TGF- $\beta 1$ $(10 \mathrm{ng} / \mathrm{ml})$ was used. In the absence of TGF- $\beta 1$, migration of $\mathrm{I} 227 \mathrm{~T} / \mathrm{N} 236 \mathrm{D}$ cells was 1.2 -fold higher than that of wild-type cells $(p<0.05)$. In the presence of TGF- $\beta 1$, I227T/N236D cells still showed 
A

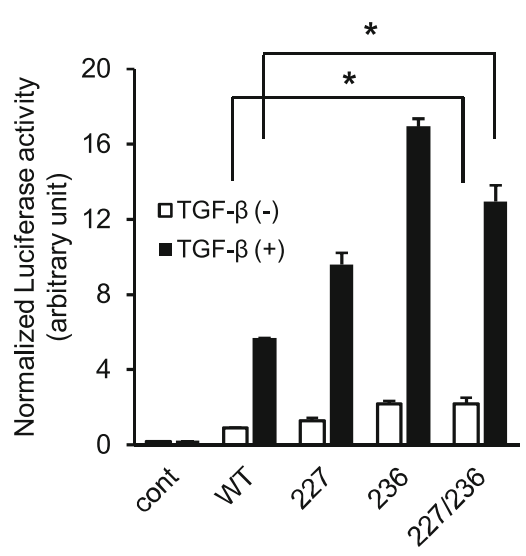

B

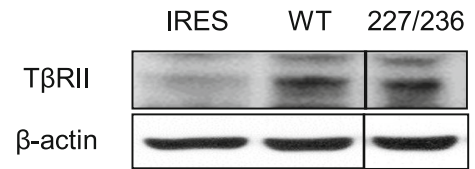

C
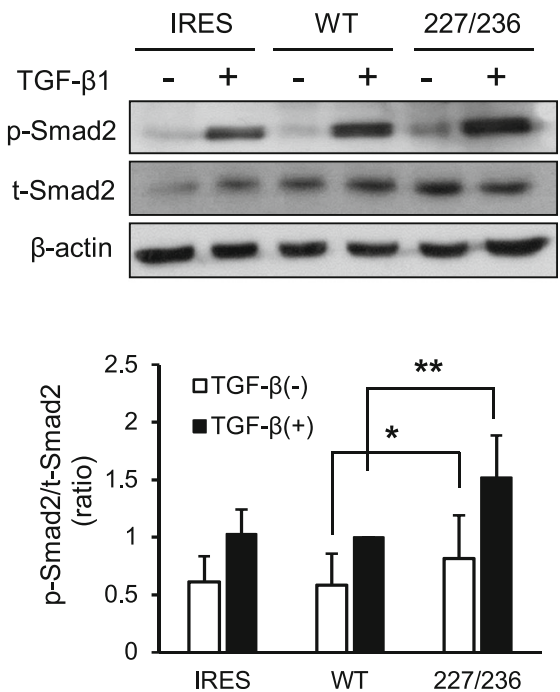

Fig. 1 Effect of I22TT/N236D TRRII mutation on TGF- $\beta$ signaling. a. Transcriptional activities were assessed via luciferase assay after transfection with pcDNA3 vector (cont), wild-type (WT), I227T (227), N236D (236), and I227T/N236D (227/236) mutant TBRII constructs. DR26 cells were co-transfected with p3TP-lux promoter-reporter construct, pRL-TK, and TBRII constructs. Transfected cells were incubated for $24 \mathrm{~h}$ in DMEM supplemented with $0.2 \% \mathrm{FBS}$ in the presence of vehicle (TGF- $\beta(-)$ ) or $1 \mathrm{ng} / \mathrm{ml}$ TGF- $\beta 1$ (TGF- $\beta(+)$ ). Transfection efficiency was normalized using Renilla luciferase. Data represent mean \pm standard deviation $\left({ }^{*} P<0.05\right)$. b. Stable transfectant cells were constructed by transfection of plRES2-EGFP vector (IRES), wild-type TRRII (WT), and I227T/N236D TRRII (227/236) constructs into HSC-2 cells. TRRIl expression in stable cells was confirmed by western blotting. Protein samples of IRES, WT, and 227/236 were separated on the same gel and the protein bands were cropped. Uncropped blots were shown in Additional file 1: Figure S1. c. Stable HSC-2 cells harboring empty vector (IRES),

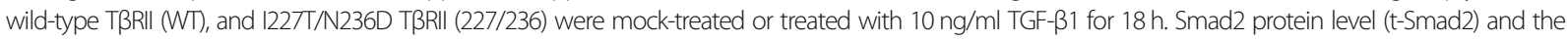
phosphorylation level of Smad2 ( $\mathrm{p}$-Smad2) were determined by western blotting. Data represent mean \pm standard deviation from three independent experiments $\left({ }^{*} P<0.05,{ }^{*} P<0.01\right)$. Full length immunoblots were shown in Additional file 2: Figure S2

A
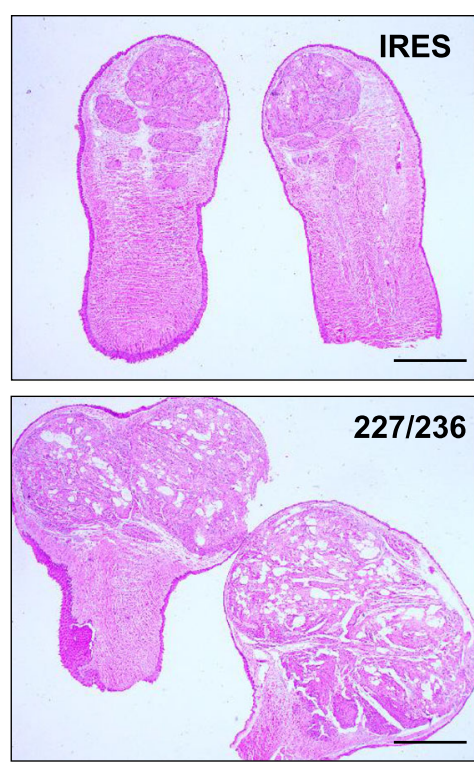

B

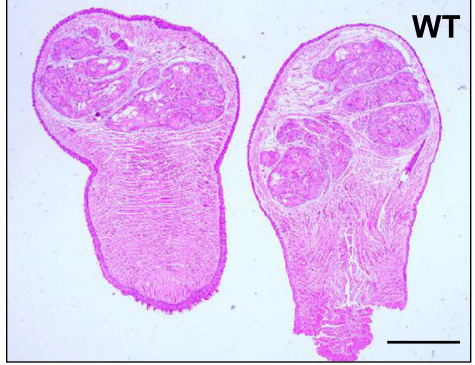

WT

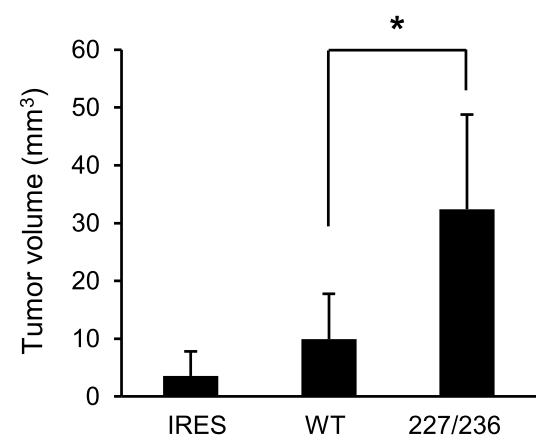

Fig. 2 Effect of I227T/N236D TRRII mutation on xenograft tumor growth. a. Stable transfectant cells harboring an empty vector (IRES), wild-type TBRII (WT), or 1227T/N236D TßRII (227/236) were orthotopically injected into the anterior tongue of mice. Tongue tumor sections were stained with H\&E. Scale bar, $1 \mathrm{~mm}$. b. Tongue tumor volume was measured at 4 weeks of injection. Data represent mean tumor volume \pm standard deviation $(* P<0.05)$ 
slightly higher migratory capabilities (1.1-fold) than wild-type TßRII cells $(p<0.05)$ (Fig. 3a). In filterbased invasion assay, I227T/N236D cells showed enhanced invasive capabilities as compared to wildtype T $\beta$ RII cells (1.4-fold) regardless of the presence of TGF- $\beta 1(p<0.05)$ (Fig. 3b).

Transcriptional activation of MMP2 and MMP9 by TGF- $\beta$ signaling is correlated with the migration and invasion of cancer cells [16]. MMP2 and MMP9 cleave the type IV and type $\mathrm{V}$ collagen and gelatin. MMP2 and MMP9 also convert latent TGF- $\beta$ to active form, creating a positive feedback loop [17, 18]. Thus, we determined the activity of MMP2 and MMP9. MMP2 activity was elevated in I227T/ N236D cells compared to wild-type cells by 1.3-fold in the presence of TGF- $\beta 1$ (Fig. $3 \mathrm{c}$, Additional file 4: Figure S4). However, MMP9 activity was decreased in wild-type cells and I227T/N236D cells, as compared to IRES. Taken together, these results indicate that I227T/N236D mutation of T $\beta$ RII promotes cell migration and invasion, at least partly, by inducing MMP2 activity.

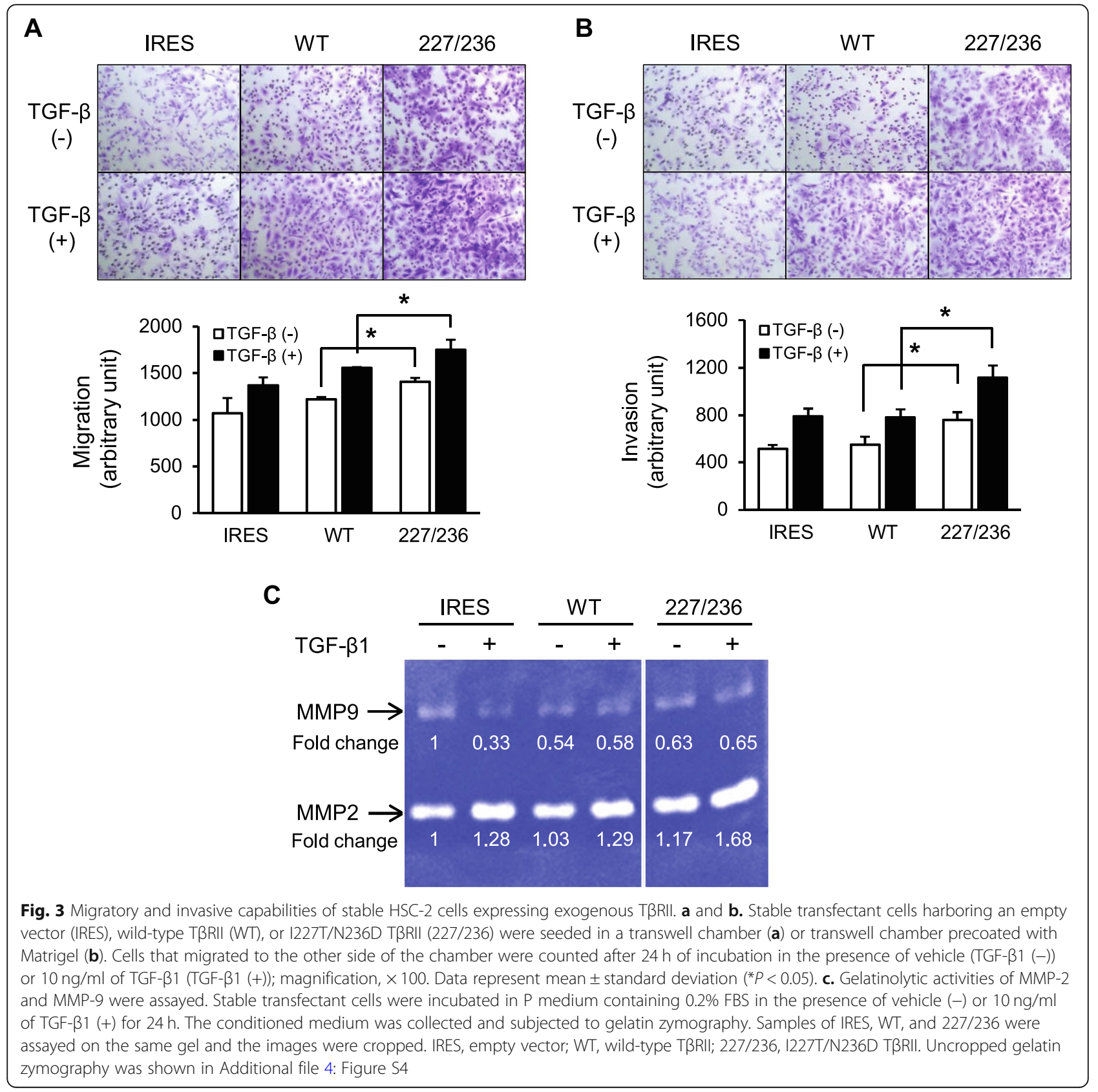




\section{I227T/N236D mutation confers resistance to apoptosis in HSC-2 cells}

In an attempt to understand the differences between in vitro and in vivo proliferative capabilities of I227T/ N236D T $\beta$ RII mutant cells, cells were treated with curcumin to induce apoptosis since apoptosis is crucial for maintaining the balance between proliferation and death of normal cells under in vivo conditions. Curcumin possesses anti-proliferative and anti-carcinogenic properties and induces apoptosis of tumor cells [19-21]. Stable transfectant cells were treated with varying concentrations of curcumin. I227T/N236D mutant cells were more resistant to proliferation inhibition by curcumin than wild-type cells when treated for 24 or $48 \mathrm{~h}$ $(p<0.01)$ (Fig. 4a). To assess whether differential sensitivity to curcumin-mediated proliferation inhibition was related to apoptotic resistance, Annexin V staining was performed following treatment with curcumin. Consistent with the results of Fig. 4a, Annexin V-positive population was significantly smaller in I227T/N236D-mutant cells than in wild type cells after curcumin treatment $(p<0.05)$ (Fig. $4 \mathrm{~b})$. To confirm this result, the levels of cleaved caspase- 3 and cleaved PARP were assayed by western blotting (Fig. 4c, Additional file 5: Figure S5). The levels of cleaved caspase-3 and cleaved PARP increased upon treatment with curcumin in a dose-dependent manner in all stable cells $(p<0.05)$. However, the levels of both cleaved caspase- 3 and cleaved PARP were significantly lower in I227T/N236D mutant cells as compared to wild-type cells. Taken together, these results suggest that I227T/N236D mutation of T $\beta$ RII confers apoptotic resistance to $\mathrm{HSC}-2$ stable cells.

\section{EGFR activation by I227T/N236D mutation}

We next analyzed the activation of pro-survival molecules involved in TGF- $\beta$ signaling cascade, such as EGFR and AKT. Upon treatment with TGF- $\beta 1$ the phosphorylation of EGFR was enhanced in all transfectant cells (Fig. 5a, Additional file 6: Figure S6). Activation of EGFR was higher in I227T/N236D T $\beta$ RII mutant cells as compared to IRES and wild-type cells in the presence of TGF- $\beta 1 \quad(p<0.01)$ indicating that enhanced TGF- $\beta$ signaling results in EGFR activation in HSC-2 cells. Similar to TGF- $\beta 1$ treatment, curcumin treatment also induced EGFR activation $(p<0.01)$, suggesting that curcumin induces not only apoptotic signaling but also prosurvival signaling. The I227T/N236D T $\beta$ RII mutant cells showed higher activation of EGFR and AKT than wildtype cells when treated with curcumin (Fig. 5b, Additional file 7: Figure S7). These results indicate that I227T/N236D mutation of TßRII induces relatively stronger pro-survival signaling than the wild-type counterpart.
To confirm the involvement of enhanced EGFR activation in I227T/N236D mutant cell survival upon curcumin treatment, cells were treated with AG1478, an EGFR inhibitor. Curcumin-induced EGFR activation was efficiently blocked by AG1478 in all stable cells $(p<0.05)$ (Fig. 5c, Additional file 8: Figure S8). I227T/N236D mutant cell viability upon curcumin treatment was reduced to the level of IRES and wildtype cells following AG1478 treatment $(p<0.05)$, indicating that EGFR mediates the pro-survival signaling of I227T/N236D mutant cells (Fig. 5d). Taken together, these results suggest that the expression of I227T/N236D mutant T $\beta R I I$ confers resistance against curcumin-induced apoptosis in HSC-2 cells by enhancing pro-survival signaling of EGFR.

To verify the enhanced EGFR signaling by I227T/ N236D mutation in vivo, we performed the immunohistochemical staining of phosphorylated EGFR in xenograft tongue tumor tissues. Phosphorylated EGFR was stained on the cell membrane of xenograft tumors (Fig. 5e). The staining intensity of the phosphorylated EGFR on the cell membrane was manually scored. Mean H-score of phosphorylated EGFR was significantly higher in I227T/N236D T $\beta$ RII tongue tumor sections than in wild-type sections $(p<0.05)$. Taken together, our findings suggest that I227T/ N236D TßRII mutation activates EGFR signaling, which could play a critical role in mutant cell survival.

\section{I227T/N236D T $\beta$ RII mutation enhances migratory and invasive capacities via EGFR activation}

To analyze the causal relationship between EGFR activation and migratory and invasive capabilities of I227T/ N236D mutant cells, the scratch wound healing and transwell cell invasion assays were performed after EGFR knockdown. EGFR was efficiently knockdowned by two different siRNAs targeting EGFR $(p<0.05)$ (Fig. 6a, Additional file 9: Figure S9). To determine the effect of EGFR on migratory capabilities induced by T $\beta$ RII mutation, two siRNAs targeting EGFR were co-transfected into the stable cells. EGFR knockdown not only reduced the TGF- $\beta$ signaling-promoted migratory capabilities but also significantly lowered the basal migratory capacities of all stable cells $(p<0.05)$ (Fig. 6b). This result suggests that EGFR signaling is crucial for migratory capacities of HSC- 2 cells and also mediates TGF- $\beta$ signaling-induced cell migration. The invasive capabilities of I227T/N236D cells were also significantly downregulated by EGFR knockdown $(p<0.05)$ (Fig. 6c). Taken together, these findings indicate that EGFR signaling plays a pivotal role in regulating migratory and invasive capacities of I227T/ N236D TßRII mutant cells. 
A
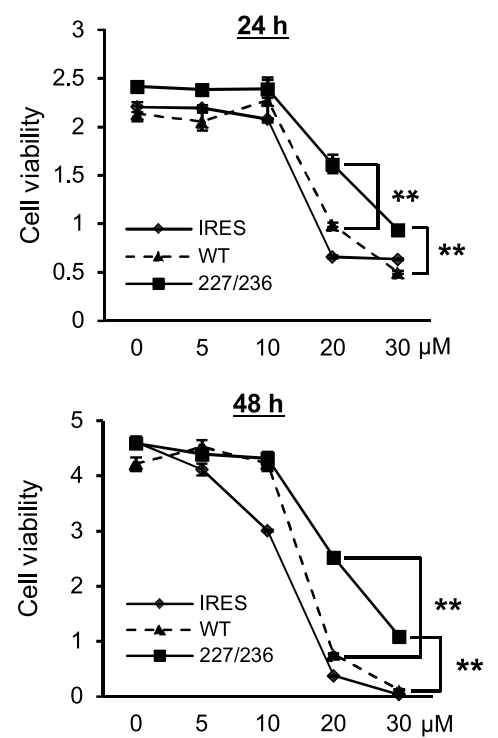

B

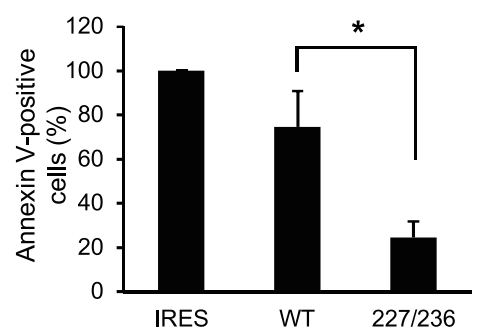

C
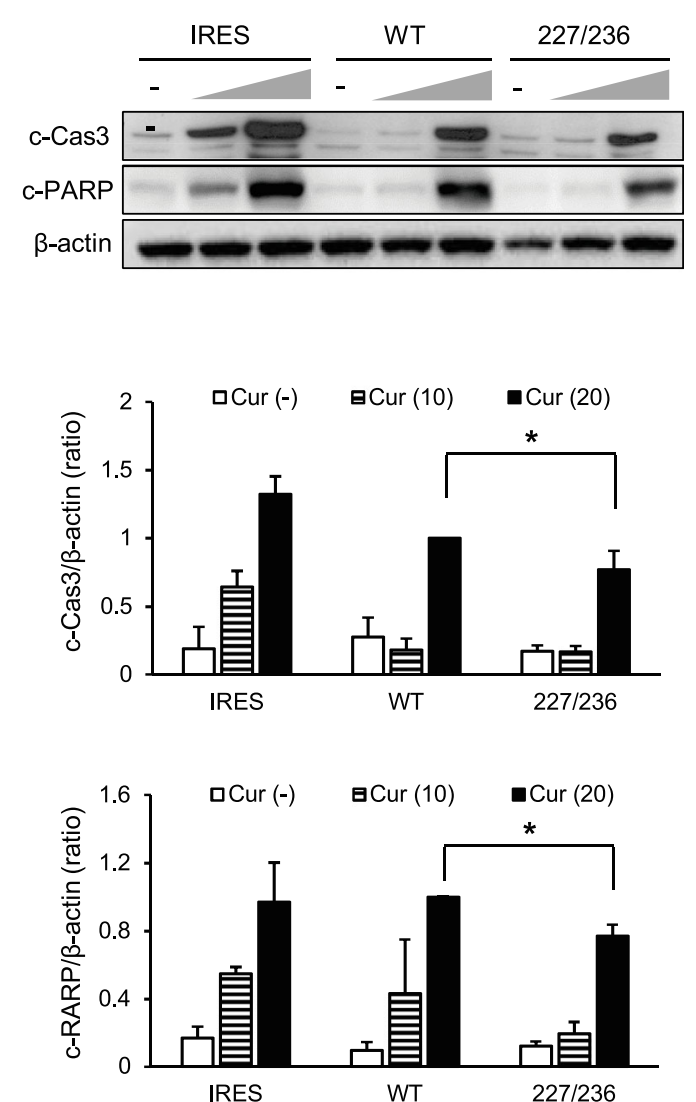

Fig. 4 Curcumin-mediated apoptotic induction in cells stably expressing exogenous TRRII. a. Stable transfectant cells were cultured with vehicle or varying concentrations of curcumin $(5-30 \mu \mathrm{M})$ for $24 \mathrm{~h}$ and $48 \mathrm{~h}$, followed by MTT assay. Data represent mean \pm standard deviation. $\left.{ }^{* *} P<0.01\right)$

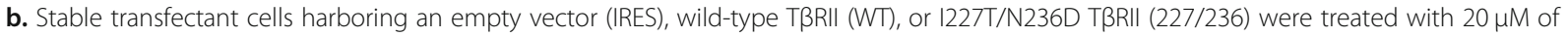
curcumin for $24 \mathrm{~h}$. Cells were stained with annexin V-FITC and Pl, followed by flow cytometric analysis. Bars represent the population of annexin V-positive cells (mean \pm standard deviation) $\left({ }^{*} P<0.05\right)$. c. Cleaved caspase-3(c-Cas3) and cleaved PARP(c-PARP) were analyzed by western blotting. Stable transfectant cells were incubated in P medium containing 0.2\% FBS in the presence of vehicle (-) or curcumin (10 and $20 \mu \mathrm{M})$ for $24 \mathrm{~h}$. Data represent mean \pm standard deviation from three independent experiments $(* P<0.05)$. IRES, empty vector; WT, wild-type TRRIl; $227 / 236$, 1227T/N236D TßRII. Full length immunoblots were shown in Additional file 5: Figure S5

\section{Discussion}

Various mutations of T $\beta$ RII have been found in a variety of tumors [7, 11, 12, 22]. However, functional studies investigating specific mutations of T $\beta$ RII from OSCC are rather scarce. The aim of the present study was to investigate the relationship between I227T/N236D mutation of TRRII and OSCC progression. The I227T/N236D mutation of T $\beta$ RII resulted in enhanced TGF- $\beta$ signaling, as revealed by higher transcriptional activities and Smad2 phosphorylation, as compared to wild-type. The transcriptional activity of T $\beta$ RII was enhanced by I227T/ $\mathrm{N} 236 \mathrm{D}$ mutation regardless of the presence of TGF- $\beta$, suggesting that this mutation could elicit conformational changes to a higher affinity form for either TGF- $\beta$ or T $\beta R I$. Another possibility for the higher transcriptional activity is that I227T/N236D mutation could modulate the rate of receptor internalization, leading to a prolonged and stronger TGF- $\beta$ signaling as was previously observed under other T $\beta$ RII mutations [10]. Underlying mechanism for the higher transcriptional activity by I227T/N236D mutation of T $\beta$ RII remains to be clarified.

To analyze the effect of I227T/N236D mutation on TGF- $\beta$ signaling in human OSCC cells, HSC- 2 cells were used. We have previously shown that HSC-2 cells exhibited TGF- $\beta$ responsiveness such as TGF- $\beta$-mediated Smad2/3 phosphorylation and EMT induction [10], suggesting that HSC- 2 cells retain an intact TGF- $\beta$ signaling machinery. Stable HSC-2 cells transfected with empty vector, wild-type T $\beta R I I$, or I227T/N236D mutant TßRII did not exhibit significant differences in growth capabilities, which indicates that enhanced TGF- $\beta$ signaling does not affect HSC-2 cell proliferation in vitro. 


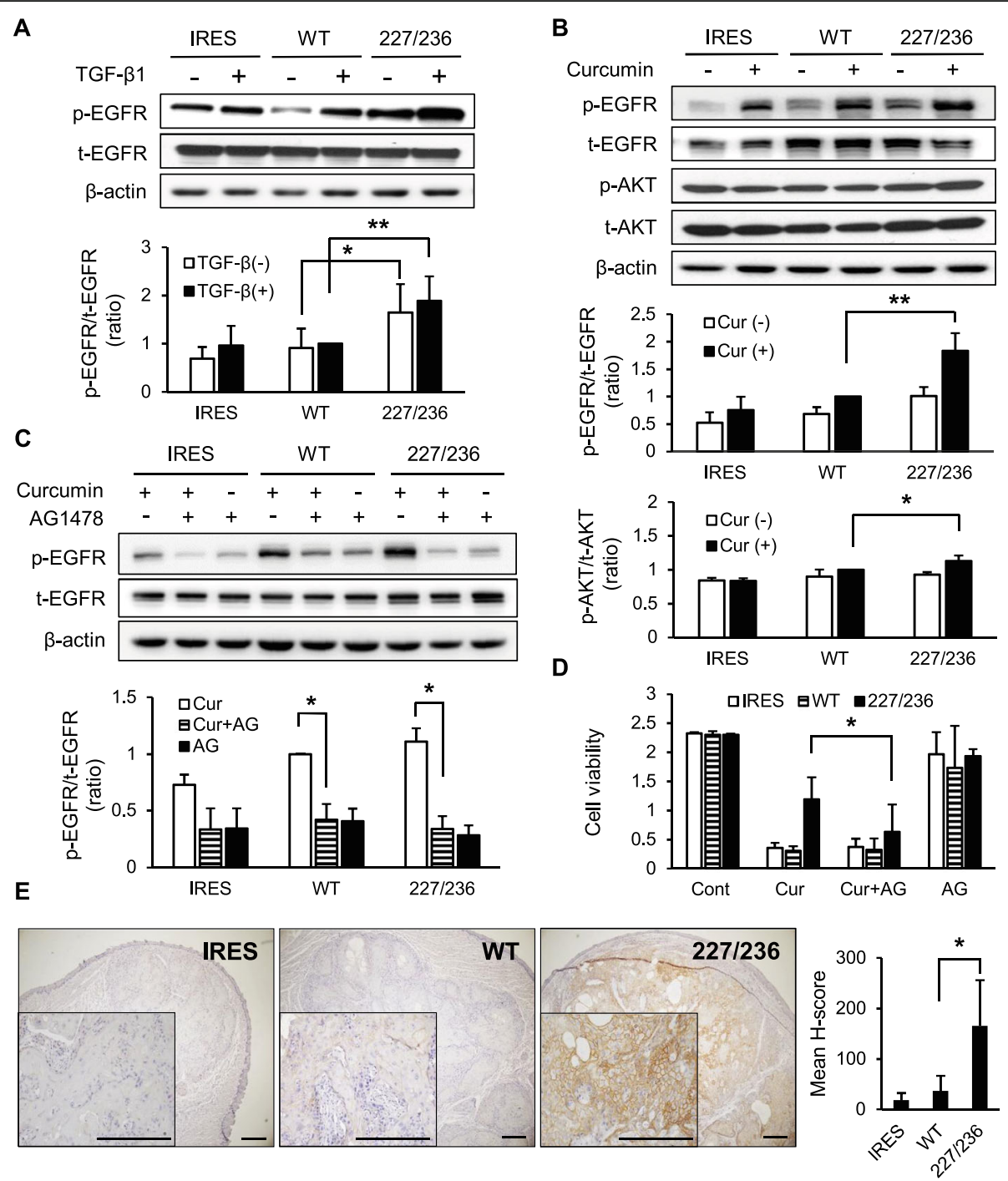

Fig. 5 Curcumin-mediated EGFR activation in stable HSC-2 cells expressing exogenous TRRII. a. Stable HSC-2 cells were incubated in P medium containing $0.2 \%$ FBS in the presence of vehicle (-) or $10 \mathrm{ng} / \mathrm{ml}$ of TGF- $\beta 1$ (+) for $24 \mathrm{~h}$. EGFR protein level (t-EGFR) and phosphorylation of EGFR (p-EGFR) were detected by western blotting. Data represent mean \pm standard deviation from three independent experiments ${ }^{*} P<0.05$, ${ }^{* *} P<$ 0.01). Full length immunoblots were shown in Additional file 6: Figure S6. b. Stable transfectant cells were incubated in $P$ medium containing $0.2 \%$ FBS in the presence of vehicle (-) or $10 \mu \mathrm{M}$ curcumin (+) for $24 \mathrm{~h}$. Activation of EGFR and AKT was detected by western blotting. t-EGFR, EGFR protein; p-EGFR, phosphorylated EGFR; t-AKT, AKT protein; $p-A K T$, phosphorylated AKT; Cur, curcumin. Data represent mean \pm standard deviation from three independent experiments. $\left({ }^{*} P<0.05,{ }^{*} P<0.01\right)$. Full length immunoblots were shown in Additional file 7 : Figure S7. c and d. Stable HSC-2 cells were incubated with 200 nM AG1478 (AG) for 30 min and treated with $10 \mu \mathrm{M}$ curcumin (Cur) for $24 \mathrm{~h}$. Activation of EGFR was determined by western blotting (c) Full length immunoblots were shown in Additional file 8: Figure S8. Cell viability was measured by MTT assay (d). Data represent mean \pm standard deviation from three independent experiments $(* P<0.05)$. e. Immunohistochemical analysis of phosphorylated EGFR in xenograft tongue tumor tissues. Magnification, $\times 40$ and $\times 200$ (inset). Scale bar, $200 \mu m$. Semiquantitative analysis of phosphorylated EGFR was performed using the $\mathrm{H}$-score method. Data represent mean \pm standard deviation $(* P<0.05)$. IRES, empty vector; WT,

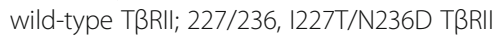

However, in xenograft tumor growth assay, the I227T/ N236D mutant TRRII exhibited around 3-fold higher tumor volume as compared to that of wild-type, implying that $\mathrm{I} 227 \mathrm{~T} / \mathrm{N} 236 \mathrm{D}$ mutation of T $\beta$ RII promotes cell proliferation in vivo. To understand the discrepancy between in vivo and in vitro proliferative capacities, we focused on the differences in cell proliferation and death signaling among two-dimensional (2D) cultures, in vitro three-dimensional (3D) cultures, and in vivo growth conditions. It has previously been reported that cell proliferation rate is lower in 3D cell culture than in 2D culture as evidenced by the increased number of apoptotic cells and reduced S-phase cell population [23, 24]. Apoptosis also occurs during tumor progression in vivo, 
A
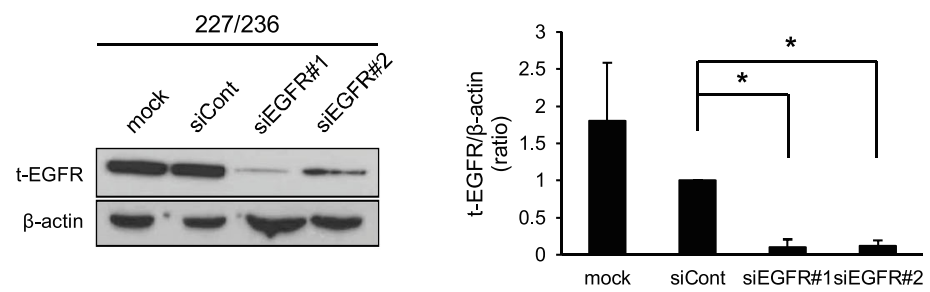

\begin{tabular}{|c|c|c|c|c|}
\hline B & IRES & \multicolumn{2}{|c|}{ WT } & $227 / 236$ \\
\hline
\end{tabular}
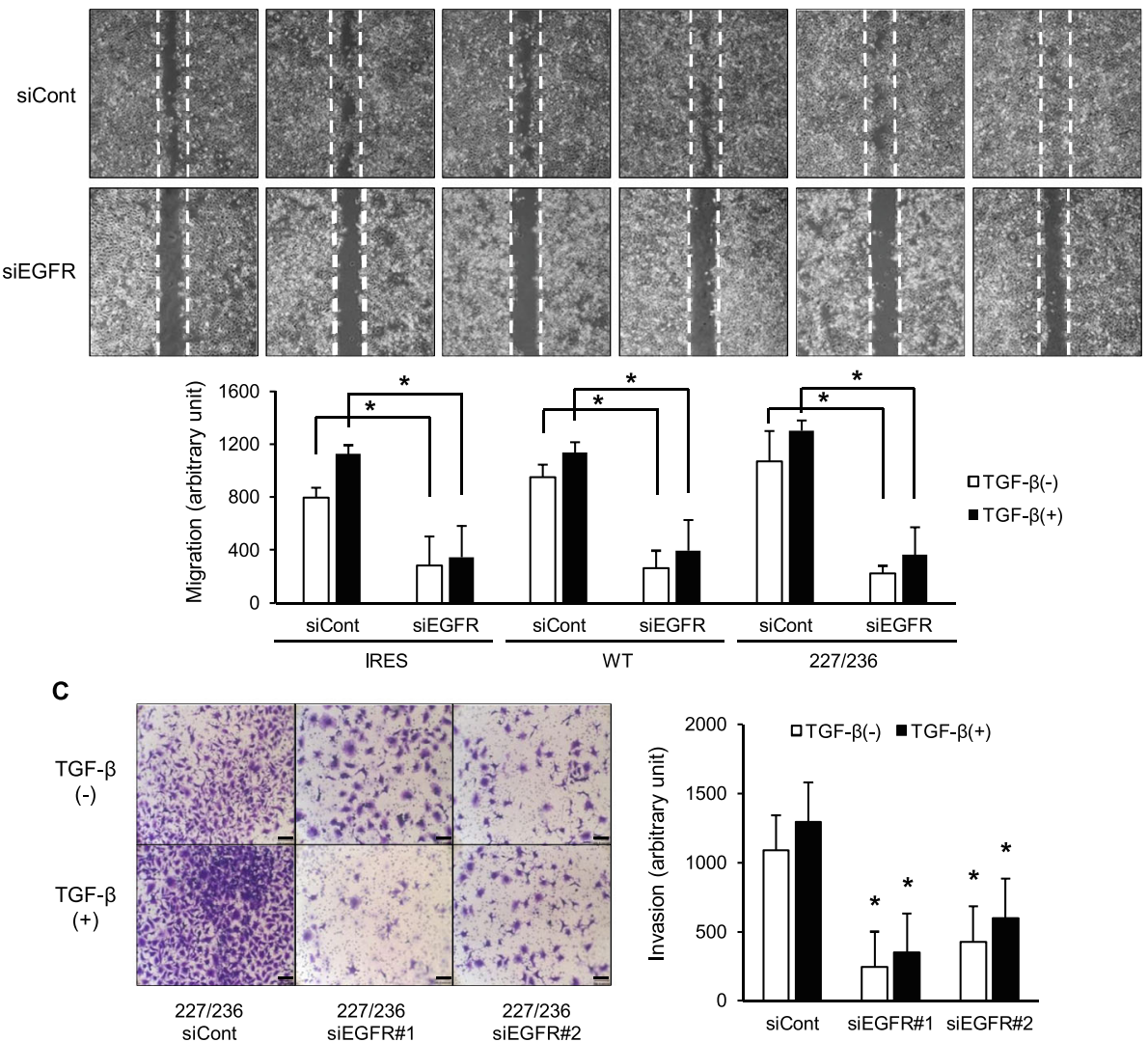

Fig. 6 Effects of EGFR on migratory and invasive capabilities of I227T/N236D TßRII-expressing stable cells. a. I227T/N236D TßRII stable cells (227/ 236) were mock transfected (mock) or transfected with control siRNA (siCont) and two siRNAs targeting EGFR (siEGFR\#1 and siEGFR\#2). Protein level of EGFR was analyzed by western blotting. Data represent mean \pm standard deviation from three independent experiments $\left({ }^{*} P<0.05\right)$. Full length immunoblots were shown in Additional file 9: Figure S9. b. Stable cells were transfected with control siRNA (siCont) or co-transfected with two siRNAs targeting EGFR (siEGFR) and stabilized for $48 \mathrm{~h}$, and then, a scratch wound was introduced in a cell monolayer, followed by incubation for $18 \mathrm{~h}$ in serum-free medium with vehicle (TGF- $\beta(-)$ ) or $10 \mathrm{ng} / \mathrm{ml}$ of TGF- $\beta 1$ (TGF- $\beta(+)$ ). All migrated cells were counted. Data represent mean \pm standard deviation ( ${ }^{*} P<0.05$, vs. control siRNA group). IRES, empty vector; WT, wild-type T $\beta R I l ;$;227/236, I227T/N236D T $\beta R I I$. c. After siRNA transfection as in (b), 1227T/N236D (227/236) cells were seeded in a transwell chamber precoated with Cellmatrix Type I-A. Cells that invaded the lower chamber were counted after $48 \mathrm{~h}$ of incubation in the presence of vehicle (TGF- $\beta(-)$ ) or $10 \mathrm{ng} / \mathrm{ml}$ of TGF- $\beta 1$ (TGF- $\beta$ (+)). Invaded cells were counted in five microscopic fields. Data represent mean \pm standard deviation ${ }^{*} P<0.05$, vs. control siRNA group)

which plays a critical role by imposing a highly selective pressure enabling clonal expansion of aggressive subclones $[25,26]$. The evasion of apoptosis in response to stress stimuli is thus an acquired hallmark of cancer. Differences in local availability of oxygen, nutrients, and signaling molecules within $3 \mathrm{D}$ culture or under in vivo conditions, are known factors that drive the variable cellular responses depending on their location [24]. We wondered, in this context, whether differential in vivo growth capacities of HSC-2 stable cells expressing wildtype and I227T/N236D mutant T/RII are due to varying susceptibilities to apoptotic stimuli of these cells. We thus analyzed apoptosis in 2D culture conditions after treatment with apoptotic inducers, such as curcumin. The I227T/N236D mutant stable cells were more resistant to apoptosis as compared to wild-type cells following 
treatment with apoptotic inducers. These results suggest that the enhanced TGF- $\beta$ signaling of I227T/N236D mutant TRRII cells contribute to enhanced in vivo proliferative capacities of these cells via suppression of apoptosis.

In response to stress stimuli, cancer cells not only acquire resistance to apoptosis but also induce survival signaling that is tightly linked. The balance between survival and death signaling controls the tumor growth [26, 27]. Survival signaling involves abnormal activation of growth stimulating molecules, such as epidermal growth factor (EGF), plateletderived growth factor (PDGF), nuclear factor $\kappa B(\mathrm{NF}-\kappa \mathrm{B})$, interleukins 2 and 3, mitogen-activated protein kinase (MAPK), and PI3K/AKT [25, 28, 29]. Our data showed that EGFR signaling was enhanced by curcumin in HSC-2 stable cells, and upregulation of TGF- $\beta$ signaling further promoted curcumin-mediated EGFR signaling. These results indicate that EGFR signaling acts as an important survival mechanism in I227T/N236D T $\beta R I I$ stable cells. A number of reports have revealed that enhanced EGFR signaling disrupts the balance between cell growth and apoptosis during development of a variety of solid tumors [30,31]. Abnormal activation of EGFR is known to occur mainly via overexpression, mutation, or autocrine stimulation of EGFR in cancers [30-32]. Transactivation of EGFR by TGF- $\beta$ signaling has also been documented in breast, gastric cancer cells, and hepatocytes [33-36]. Taken together, our results indicate that EGFR activation via enhanced TGF- $\beta$ signaling might play a critical role in tumor progression of OSCC by promoting cell survival.

Curcumin is a polyphenol found in the rhizome of Curcuma longa and exhibits nontoxic chemopreventive and chemotherapeutic activities [20]. Curcumin has been shown to induce apoptosis in a variety of cancer cells [37-40]. We used curcumin as an apoptotic inducer since these seemingly opposite effects could be gradually modulated by controlling the dose. Since curcumin has various molecular targets, diverse apoptotic and growth inhibitory signaling pathways are modulated by curcumin treatment. Several reports have shown that curcumin inhibits EGFR signaling via suppression of EGFR expression, induction of EGFR degradation, inhibition of kinase activity of EGFR, and modulation of EGFR dimerization in lung adenocarcinoma, colon cancer, and epidermoid carcinoma cell lines [19, 21, 41]. Curcumin induced apoptosis of HSC-2 cells at a concentration of $20 \mu \mathrm{M}$ in $24 \mathrm{~h}$. However, curcumin concentrations lower than $20 \mu \mathrm{M}$ did not induce significant apoptosis in $24 \mathrm{~h}$, but activated EGFR in all stable cells. We speculated that the exposure of HSC-2 cells to low concentrations of curcumin can activate pro-survival EGFR signaling as well as death signaling. EGFR signaling was higher in HSC-2 cells expressing I227T/N236D mutant TßRII than in wild-type counterpart. Concomitant with higher
EGFR activation, the level of cleaved caspase-3 was lower in mutant cells than in wild-type cells upon curcumin treatment. AG1478, a pharmacological inhibitor of EGFR, efficiently suppressed EGFR activation, which led to the abrogation of apoptotic resistance of I227T/ N236D mutant cells. Taken together, these results suggest that EGFR activation via enhanced TGF- $\beta$ signaling is critical for the evasion of HSC-2 stable cells from apoptosis, which further supports the notion that I227T/ N236D mutation of T $\beta$ RII plays an important role in cell proliferation in vivo.

TGF- $\beta$ treatment enhanced the migratory and invasive activities of HSC-2 cells. The I227T/N236D mutant TßRII cells exhibited higher migratory and invasive capabilities compared to wild-type cells regardless of the presence of TGF- $\beta$. To validate the role of EGFR in regulating migratory and invasive capabilities of I227T/ N236D TRRII stable cells, EGFR was knockdowned in mutant cells. EGFR silencing dramatically reduced migratory and invasive capabilities of I227T/N236D T $\beta$ RII cells, indicating that EGFR signaling plays a pivotal role in cell migration and invasion as well as in proliferation of OSCC.

In summary, our findings suggest that enhanced TGF$\beta$ signaling via I227T/N236D mutation of T $\beta$ RII promotes EGFR activation, leading to tumorigenesis of OSCC by enhancing the hallmark features of cancer, such as apoptotic resistance and more invasive phenotypic changes.

\section{Conclusion}

This study shows the relationship between a novel T $\beta R I I$ mutation detected in the metastatic lymph node of a patient, I227T/N236D, on oral squamous cell carcinoma progression. We identified that I227T/N236D mutation can enhance proliferative capacities and apoptotic resistance via upregulated TGF- $\beta$ signaling. Furthermore, EGFR activation is involved in proliferative capabilities and apoptotic resistance as well as in migratory and invasive capacities of I227T/N236D T $\beta$ RII cells. These findings will provide the development of new therapeutic approach for metastatic OSCC patients.

\section{Supplementary Information}

The online version contains supplementary material available at https://doi. org/10.1186/s12885-020-07669-5.

\footnotetext{
Additional file 1: Figure S1. Full length immunoblots of T $\beta R \|$ and $\beta$ actin in Fig. 1b. Stable transfectant cells were constructed by transfection

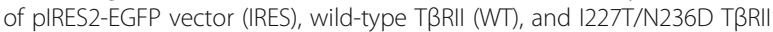
(227/236) constructs into HSC-2 cells. T $\beta$ RII expression in stable cells was confirmed by western blotting. Protein samples were run in two identical sets and transferred to PVDF membranes. Protein samples of IRES, WT, and $227 / 236$ were separated on the same gel and the corresponding protein bands were cropped. The red rectangle represents the cropping area.
} 
Additional file 2: Figure S2. Full length immunoblots of $\mathrm{p}-\mathrm{Samd2}$, $\mathrm{t}$ Smad2 and $\beta$-actin in Fig. 1c. Stable HSC-2 cells harboring empty vector

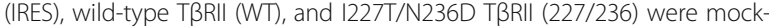
treated or treated with $10 \mathrm{ng} / \mathrm{ml}$ TGF- $\beta 1$ for $18 \mathrm{~h}$. Smad2 protein level (tSmad2) and the phosphorylation level of Smad2 (p-Smad2) were determined by western blotting. Protein samples were run in three identical sets and transferred to PVDF membranes. Membranes were probed with p-Smad 2 antibodies, Smad 2 antibodies and $\beta$-actin antibodies, respectively.

Additional file 3: Figure S3. The growth of stable transfectant cells harboring an empty vector (IRES), wild-type T $\beta$ RII (WT), or I227T/N236D TRRII (227-236). The stable cells were cultured in the presence of vehicle $(-)$ or $10 \mathrm{ng} / \mathrm{mL}$ of TGF- $\beta 1$ (+) for up to 4 days. Cell proliferation was measured by MTT assay. Data represent mean \pm standard deviation. ${ }^{*} P<0.05$ (mutant vs. wild-type).

Additional file 4: Figure S4. Full length gelatin zymography in Fig. 3c. Gelatinolytic activities of MMP-2 and MMP-9 were assayed. Stable transfectant cells were incubated in P medium containing $0.2 \% \mathrm{FBS}$ in the presence of vehicle (-) or $10 \mathrm{ng} / \mathrm{ml}$ of TGF- $\beta 1$ (+) for $24 \mathrm{~h}$. The conditioned medium was collected and subjected to gelatin zymography. Samples of IRES, WT, and 227/236 were assayed on the same gel and the corresponding images were cropped. The red rectangle represents the cropping area.

Additional file 5: Figure S5. Full length immunoblots of Cleaved caspase-3(c-Cas3) and cleaved PARP(c-PARP) and $\beta$-actin in Fig. 4c. Stable transfectant cells were incubated in P medium containing $0.2 \% \mathrm{FBS}$ in the presence of vehicle $(-)$ or curcumin $(10 \mu \mathrm{M}$ and $20 \mu \mathrm{M})$ for $24 \mathrm{~h}$. Protein samples were run in three identical sets and transferred to PVDF membranes. Membranes were probed with c-Cas3 antibodies, c-PARP antibodies and $\beta$-actin antibodies, respectively.

Additional file 6: Figure S6. Full length immunoblots of EGFR protein level (t-EGFR), phosphorylation of EGFR (p-EGFR) and $\beta$-actin in Fig. 5 a. Stable HSC-2 cells were incubated in P medium containing $0.2 \%$ FBS in the presence of vehicle $(-)$ or $10 \mathrm{ng} / \mathrm{ml}$ of TGF- $\beta 1$ (+) for $24 \mathrm{~h}$. EGFR protein level (t-EGFR) and phosphorylation of EGFR (p-EGFR) were detected by western blotting. Same protein samples were run three times and transferred to PVDF membranes. Each membrane was cut into two parts and the membrane parts harboring target protein bands were probes with the corresponding antibodies.

Additional file 7: Figure S7. Full length immunoblots of EGFR protein level (t-EGFR), phosphorylation of EGFR ( $p$-EGFR), AKT protein level (tAKT), phosphorylation of AKT (p-AKT) and $\beta$-actin in Fig. 5b. Stable transfectant cells were incubated in P medium containing $0.2 \%$ FBS in the presence of vehicle (-) or $10 \mu \mathrm{M}$ curcumin (+) for $24 \mathrm{~h}$. Activation of EGFR and AKT was detected by western blotting. Protein samples were run in three identical sets and transferred to PVDF membranes. First membrane was probed with p-EGFR antibodies. Second membrane was probed with p-AKT, followed by stripping and reprobing with AKT antibodies. Third membrane was cut into two parts. Upper part was probed with EGFR antibodies and the lower part was probed with $\beta$-actin antibodies.

Additional file 8: Figure S8. Full length immunoblots of EGFR protein level (t-EGFR), phosphorylation of EGFR ( $p$-EGFR) and $\beta$-actin in Fig. $5 c$. Stable HSC-2 cells were incubated with 200 nM AG1478 (AG) for 30 min and treated with $10 \mu \mathrm{M}$ curcumin (Cur) for $24 \mathrm{~h}$. Activation of EGFR was determined by western blotting. Protein samples were run in two identical sets and transferred to PVDF membranes. First membrane was probed with p-EGFR antibodies. Second membrane was cut into two parts. Upper part was probed with EGFR antibodies and the lower part was probed with $\beta$-actin antibodies.

Additional file 9: Figure S9. Full length immunoblots of EGFR protein level (t-EGFR) and $\beta$-actin in Fig. 6a. 1227T/N236D TßRIl stable cells (227/ 236) were mock transfected (mock) or transfected with control siRNA (siCont) and two siRNAs targeting EGFR (siEGFR\#1 and siEGFR\#2). Protein level of EGFR was analyzed by western blotting. Protein samples were run in two identical sets and transferred to PVDF membranes. First membrane was probed with EGFR antibodies and the second membrane was probed with $\beta$-actin antibodies.

\section{Abbreviations}

TGF- $\beta$ : Transforming growth factor- $\beta$; T $\beta R$ Rll: Transforming growth factor- $\beta$ receptor II; OSCC: Oral squamous cell carcinoma; EGFR: Epidermal growth factor receptor; MAPKs: Mitogen-activated protein kinases; EMT: Epithelialmesenchymal transition; MMP: Matrix metalloproteinase; PDGF: Plateletderived growth factor; NF-kB: Nuclear factor $\mathrm{kB}$

\section{Acknowledgements}

Not applicable.

\section{Authors' contributions}

All authors read and approved the final manuscript before submission. All authors have made a sufficient contribution to the work. SHK, IP, and JK designed the experiments. SHK and IP performed the mutant construction and stable cell line generation. SHK, DKK, and YL conducted the experiments and analyzed the data with inputs from IP and JK. DKK and IP wrote the manuscript. IP and JK revised the manuscript.

\section{Funding}

This research was supported by Basic Science Research Program through the National Research Foundation of Korea (NRF) funded by the Ministry of Education (NRF-2019R111A3A01062555).

\section{Availability of data and materials}

The datasets generated in and/or analyzed from the current study are available in Genbank, MW262807.

\section{Ethics approval and consent to participate}

This study was approved by the Institutional Animal Care and Use Committee of Yonsei University (IRB-2-2009-0002). The study was carried out in accordance with the guidelines for the care and use of animals including in the approved protocol. None of the cell lines used in the present study required ethics approval for their use.

\section{Consent for publication}

Not applicable.

\section{Competing interests}

The authors declare that they have no competing interests.

\section{Author details}

'Department of Dental Hygiene, Yeungnam University College, Daegu 42415, Republic of Korea. ${ }^{2}$ Department of Dental Hygiene, Jeonju Kijeon College, Jeonju 54989, Republic of Korea. ${ }^{3}$ Department of Oral Pathology, Oral Cancer Research Institute, BK21 PLUS Project, Yonsei University College of Dentistry, Seoul 03722, Republic of Korea. ${ }^{4}$ Department of Biochemistry, Department of Biomedical Sciences, Research Institute of Medical Sciences, Chonnam National University Medical School, Hwasun 58128, Republic of Korea. ${ }^{5}$ Department of Biochemistry, Research Center for Aging and Geriatrics, Research Institute of Medical Sciences, Chonnam National University Medical School, Hwasun 58128, Republic of Korea.

Received: 28 February 2020 Accepted: 20 November 2020

Published online: 27 November 2020

\section{References}

1. Massague J. TGFbeta in cancer. Cell. 2008;134(2):215-30.

2. Kojima Y, Acar A, Eaton EN, Mellody KT, Scheel C, Ben-Porath I, Onder T, Wang ZC, Richardson AL, Weinberg RA, et al. Autocrine TGF-beta and stromal cell-derived factor-1 (SDF-1) signaling drives the evolution of tumorpromoting mammary stromal myofibroblasts. Proc Natl Acad Sci U S A. 2010;107(46):20009-14

3. Kubiczkova L, Sedlarikova L, Hajek R, Sevcikova S. TGF-beta - an excellent servant but a bad master. J Transl Med. 2012;10:183.

4. Vander Ark A, Cao J, Li X. TGF-beta receptors: in and beyond TGF-beta signaling. Cell Signal. 2018;52:112-20.

5. Wrana JL, Attisano L, Carcamo J, Zentella A, Doody J, Laiho M, Wang XF, Massague J. TGF beta signals through a heteromeric protein kinase receptor complex. Cell. 1992;71(6):1003-14.

6. Wrana JL, Attisano L, Wieser R, Ventura F, Massague J. Mechanism of activation of the TGF-beta receptor. Nature. 1994;370(6488):341-7. 
7. Derynck R, Akhurst RJ, Balmain A. TGF-beta signaling in tumor suppression and cancer progression. Nat Genet. 2001;29(2):117-29.

8. Miyazono K, ten Dijke P, Heldin CH. TGF-beta signaling by Smad proteins. Adv Immunol. 2000;75:115-57.

9. Tang J, Gifford CC, Samarakoon R, Higgins PJ. Deregulation of negative controls on TGF-beta1 signaling in tumor progression. Cancers. 2018;10(6): 159. https://doi.org/10.3390/cancers10060159.

10. Park I, Son HK, Che ZM, Kim J. A novel gain-of-function mutation of TGFbeta receptor II promotes cancer progression via delayed receptor internalization in oral squamous cell carcinoma. Cancer Lett. 2012;315(2): 161-9.

11. Levy L, Hill CS. Alterations in components of the TGF-beta superfamily signaling pathways in human cancer. Cytokine Growth Factor Rev. 2006; 17(1-2):41-58.

12. Lee EH, Bae KJ, Kim TK, Park H-S, Lee EJ, Kim J. Genetic mutation of transforming growth factor beta type $\|$ receptor in oral squamous cell carcinoma. Basic Appl Pathol. 2009;2(3):82-8.

13. Lee GHCJ, Kim EJ, Lee EJ, Kim J. The inhibitory effect of TGF-b1 in oral squamous cell carcinoma proliferation. Korean J Oral Maxillofac Pathol. 2006;30:143-50.

14. Carlsson G, Gullberg B, Hafstrom L. Estimation of liver tumor volume using different formulas - an experimental study in rats. J Cancer Res Clin Oncol. 1983;105(1):20-3.

15. Rojas A, Padidam M, Cress D, Grady WM. TGF-beta receptor levels regulate the specificity of signaling pathway activation and biological effects of TGFbeta. Biochim Biophys Acta. 2009;1793(7):1165-73.

16. Gomes LR, Terra LF, Wailemann RA, Labriola L, Sogayar MC. TGF-beta1 modulates the homeostasis between MMPs and MMP inhibitors through p38 MAPK and ERK1/2 in highly invasive breast cancer cells. BMC Cancer. 2012;12:26.

17. Sternlicht MD, Werb Z. How matrix metalloproteinases regulate cell behavior. Annu Rev Cell Dev Biol. 2001;17:463-516.

18. Yu Q, Stamenkovic I. Cell surface-localized matrix metalloproteinase-9 proteolytically activates TGF-beta and promotes tumor invasion and angiogenesis. Genes Dev. 2000;14(2):163-76.

19. Lee JY, Lee YM, Chang GC, Yu SL, Hsieh WY, Chen JJ, Chen HW, Yang PC. Curcumin induces EGFR degradation in lung adenocarcinoma and modulates p38 activation in intestine: the versatile adjuvant for gefitinib therapy. PLoS One. 2011;6(8):e23756.

20. Zhou QM, Wang XF, Liu XJ, Zhang H, Lu YY, Su SB. Curcumin enhanced antiproliferative effect of mitomycin C in human breast cancer MCF-7 cells in vitro and in vivo. Acta Pharmacol Sin. 2011;32(11):1402-10

21. Chen $\mathrm{A}, \mathrm{Xu}$ J, Johnson AC. Curcumin inhibits human colon cancer cell growth by suppressing gene expression of epidermal growth factor receptor through reducing the activity of the transcription factor Egr-1. Oncogene. 2006;25(2):278-87.

22. Fukuchi M, Masuda N, Miyazaki T, Nakajima M, Osawa $H$, Kato H, Kuwano H. Decreased Smad4 expression in the transforming growth factor-beta signaling pathway during progression of esophageal squamous cell carcinoma. Cancer. 2002;95(4):737-43.

23. Riedl A, Schlederer M, Pudelko K, Stadler M, Walter S, Unterleuthner D, Unger C, Kramer N, Hengstschlager M, Kenner L, et al. Comparison of cancer cells in 2D vs 3D culture reveals differences in AKT-mTOR-S6K signaling and drug responses. J Cell Sci. 2017;130(1):203-18.

24. Kapalczynska M, Kolenda T, Przybyla W, Zajaczkowska M, Teresiak A, Filas V, Ibbs M, Blizniak R, Luczewski L, Lamperska K. 2D and 3D cell cultures - a comparison of different types of cancer cell cultures. Arch Med Sci. 2018; 14(4):910-9.

25. Fulda S. Tumor resistance to apoptosis. Int J Cancer. 2009;124(3):511-5.

26. Fulda S. Evasion of apoptosis as a cellular stress response in cancer. Int J Cell Biol. 2010;2010:370835

27. Labi V, Erlacher M. How cell death shapes cancer. Cell Death Dis. 2015;6: e1675.

28. Igney $\mathrm{FH}, \mathrm{Krammer} \mathrm{PH}$. Death and anti-death: tumour resistance to apoptosis. Nat Rev Cancer. 2002;2(4):277-88.

29. Yilmaz $M$, Maass $D$, Tiwari $N$, Waldmeier $L$, Schmidt $P$, Lehembre F, Christofori $G$. Transcription factor Dlx2 protects from TGFbeta-induced cellcycle arrest and apoptosis. EMBO J. 2011:30(21):4489-99.

30. Normanno N, De Luca A, Bianco C, Strizzi L, Mancino M, Maiello MR, Carotenuto A, De Feo G, Caponigro F, Salomon DS. Epidermal growth factor receptor (EGFR) signaling in cancer. Gene. 2006;366(1):2-16.
31. Jorissen RN, Walker F, Pouliot N, Garrett TP, Ward CW, Burgess AW. Epidermal growth factor receptor: mechanisms of activation and signalling. Exp Cell Res. 2003;284(1):31-53.

32. Del Castillo G, Murillo MM, Alvarez-Barrientos A, Bertran E, Fernandez M, Sanchez A, Fabregat I. Autocrine production of TGF-beta confers resistance to apoptosis after an epithelial-mesenchymal transition process in hepatocytes: role of EGF receptor ligands. Exp Cell Res. 2006;312(15):2860-71.

33. Uchiyama-Tanaka Y, Matsubara H, Mori Y, Kosaki A, Kishimoto N, Amano K, Higashiyama S, Iwasaka T. Involvement of HB-EGF and EGF receptor transactivation in TGF-beta-mediated fibronectin expression in mesangial cells. Kidney Int. 2002;62(3):799-808.

34. Ebi M, Kataoka H, Shimura T, Kubota E, Hirata Y, Mizushima T, Mizoshita T, Tanaka M, Mabuchi M, Tsukamoto H, et al. TGFbeta induces proHB-EGF shedding and EGFR transactivation through ADAM activation in gastric cancer cells. Biochem Biophys Res Commun. 2010:402(3):449-54.

35. Moreno-Caceres J, Caja L, Mainez J, Mayoral R, Martin-Sanz P, MorenoVicente R, Del Pozo MA, Dooley S, Egea G, Fabregat I. Caveolin-1 is required for TGF-beta-induced transactivation of the EGF receptor pathway in hepatocytes through the activation of the metalloprotease TACE/ADAM17. Cell Death Dis. 2014;5:e1326.

36. Li L, Qi L, Liang Z, Song W, Liu Y, Wang Y, Sun B, Zhang B, Cao W. Transforming growth factor-beta1 induces EMT by the transactivation of epidermal growth factor signaling through HA/CD44 in lung and breast cancer cells. Int J Mol Med. 2015;36(1):113-22.

37. Hilchie AL, Furlong SJ, Sutton K, Richardson A, Robichaud MR, Giacomantonio CA, Ridgway ND, Hoskin DW. Curcumin-induced apoptosis in PC3 prostate carcinoma cells is caspase-independent and involves cellular ceramide accumulation and damage to mitochondria. Nutr Cancer. 2010;62(3):379-89.

38. Watson JL, Greenshields A, Hill R, Hilchie A, Lee PW, Giacomantonio CA, Hoskin DW. Curcumin-induced apoptosis in ovarian carcinoma cells is p53independent and involves p38 mitogen-activated protein kinase activation and downregulation of $\mathrm{BCl}-2$ and survivin expression and Akt signaling. Mol Carcinog. 2010;49(1):13-24.

39. Wang WZ, Li L, Liu MY, Jin XB, Mao JW, Pu QH, Meng MJ, Chen XG, Zhu JY. Curcumin induces FasL-related apoptosis through p38 activation in human hepatocellular carcinoma Huh7 cells. Life Sci. 2013:92(6-7):352-8.

40. Zhu GH, Dai HP, Shen Q, Ji O, Zhang Q, Zhai YL. Curcumin induces apoptosis and suppresses invasion through MAPK and MMP signaling in human monocytic leukemia SHI-1 cells. Pharm Biol. 2016;54(8):1303-11.

41. Starok M, Preira P, Vayssade M, Haupt K, Salome L, Rossi C. EGFR inhibition by Curcumin in Cancer cells: a dual mode of action. Biomacromolecules. 2015;16(5):1634-42.

\section{Publisher's Note}

Springer Nature remains neutral with regard to jurisdictional claims in published maps and institutional affiliations.

Ready to submit your research? Choose BMC and benefit from:

- fast, convenient online submission

- thorough peer review by experienced researchers in your field

- rapid publication on acceptance

- support for research data, including large and complex data types

- gold Open Access which fosters wider collaboration and increased citations

- maximum visibility for your research: over $100 \mathrm{M}$ website views per year

At $\mathrm{BMC}$, research is always in progress.

Learn more biomedcentral.com/submission 